INTERNATIONAL JOURNAL OF RESEARCHES IN BIOSCIENCES, AGRICULTURE AND TECHNOLOGY (C) VISHWASHANTI MULTIPURPOSE SOCIETY (Global Peace Multipurpose Society) R. No. MH-659/13(N) www.vmsindia.org

\title{
ECONOMIC IMPORTANCE OF FARMER FRIENDLY WEED AMARANTHUS SPINOSUS L. IN NON IRRIGATED AGRONOMIC PATTERN OF SATARA DISTRICT
}

\author{
R. S. Bhosale \\ D.G. Walse Patil College, Pargaon, Savitribai Phule Pune University, Pune, (M.S.). \\ rahul.bhosale3@gmail.com
}

\begin{abstract}
:
Amaranthus spinosus L. is a member of family Amaranthaceae is widely distributed throughout the tropics and warm temperate regions of Asia from Japan to Indonesia to India, the Pacific islands and Australia as a weed in cultivated as well as uncultivated lands. In Indian traditional system of medicine and AyurvedaAmaranthus spinosusL.is used as digestible, laxative, diuretic, stomachic, antipyretic, improves the appetite, biliousness, blooddiseases, burning sensation, leprosy, bronchitis, piles andleucorrhoea. Its extract is used for its antiinflammatory properties, effect on hematology, immunomodulatory activity, anthelmintic properties, antidiabetic, antihyperlipidemic and spermatogenic. (Mishra et al, 2012). In Maharashtra it is commonly known as "Kate Math" or "Deth" as it is utilized as leaf vegetable when young and tender stem vegetable at time of flowering. In Satara district it is commonly known as "Dhesa" where whole stem along with roots is used as vegetable. It is most common food throughout Satara district in non irrigated and low rainfall zones. It is also a common vegetable in Narayangaon and other suburban cities of Pune district where Amaranthus spinosusL. is used as stem vegetable on sacred occasions called "Mahal".
\end{abstract}

Keywords: Amaranthusspinosus, weed, agronomic etc.

\section{Introduction}

In Maharashtra agriculture is gaining benefits of modern agriculture as a result of acceptability of farmers to innovative techniques. Efforts of state governments have lead to development of many agricultural zones by providing technology and agro literacy. Major regions in state are proved to be benefited with cumulative efforts of farmers and government agencies. This scenario is more or less similar all over Maharashtra except some non-irrigated regions. Present work aims to study Agronomic pattern of Satara district in non-irrigated and low rainfall zones. Several regions like Maan, Khatav and Khandala are facing similar tribulations which have forced to adapt environment friendly patterns of agriculture. The agro economy for these regions depends on first shower of Monsoon and winter. This pattern has made many farmers utilize some weed crops as a gift of nature. Present survey aims at study of a farmer friendly weed Amaranthus spinosusL.and its economic contribution from local market.Amaranthus spinosusL.is a annual growing to $1 \mathrm{~m}$ (3ft $3 \mathrm{in})$. It flowers in August, and the seeds ripen in September. The flowers are monoecious and are pollinated by Wind or self. Leaves are eaten raw or cooked as leaf vegetable. The leaves contain about $3.88 \%$ protein, $1.1 \%$ fat, $9.38 \%$ carbohydrate. They are very rich in Vitamins A \& $\mathrm{C}$, rich in vitamin B1. (http://www.cabi.org/isc/overview).
Amaranthus spinosusL.is well known weed in Maharashtra. Most of the times this weed is eradicated but not thrown away, rather it is used as a fresh leaf vegetable. Many farmers from Khandala block let the weed grow along with their crops and sell them in weekend bazaar (local market). It serves to be economically beneficial for minor farmers.

\section{Material and methods}

Site of study - Agriculture zones of Khandala Block, (Pargaon) Dist Satara. Near about 56 farmers from 5 zones were selected for following survey.

Duration - following survey was carried out for two years (2011-12 and 2012-13) during Monsoon and growth span of selected weed plant.

The local villages that reported conserved Amaranthusgrowth was surveyed for last two years. Farmers with non-irrigated traditional farms and minor land were mostly sort out. Datafrom farmers engaged in Amaranthus growthwas acquired from Grampanchayats and several other local sources. Meetings were held regularly with several farmers and group of farmers. More than 5 weekly markets were surveyed for studying market value of the edible weed. Financial calculations were made on basis of input cost and market values. 


\section{Result and Discussion}

Mostly the farmers of non-irrigated zones rely on conventional farming of legumes and grain crops like ground nuts, beans, chickpea, cowpea, green gram, black gram, sesame, bajara and jowar. These farmers used local seeds of previous harvest. These crops severed as livelihood food throughout year and sometimes depending on production extra produce was sold to market. Amaranthus spinosusL.was used as reliable and healthy food during vegetative phase of the plants. This weed is considered as a healthy seasonal food. These plants do not require any cultivation cost as it is a weed with huge number of minute seeds propagating very easily during monsoon. It is reported that common bean cultivars are inhibited by allopathic effect of some Amaranthus species Rouhollahet al., (2012), therefore these weeds are not conserved in some modern agricultural practices. Even if these plants are weeds they do not affect growth of crop plants as they are regularly uprooted for food and market value. During growth period along with other leaf vegetable like spinach and trigonella it is sold in local market with nearly equal price as they are equally nutritional or even more sometimes. In other studies conducted by Patil and Patil (2000) The use leaves, tubersrhizomes, bulbils, fruits, seeds, flowers, etc of wild plants and common weeds serve as complementary diet in times ofscarcity of food during famines. The study by Sasiet al., 2011 observed that the tribal communities fulfill their food deficiency by supplementing wild food plants in their daily diet. Common weeds prove to be an interesting resource in small to medium-sized human settlements where they may provide supplementary food. In large cities, suburban populations may also profit from edible weedsMartha et al., 1999. It is also reported that some wild Mediterranean plants used as traditional food are an extraordinary source of antioxidants Paola (2011).

In spite of nutritional importance of some common weed species they are less looked and cultured. It certainly deserves more attention to determine wider domestication possibilities and optimum cultivation practices. Jansen, (2004). A common solution on such problems may be promotion of traditional farming, but the trend of economic development in farming has shown deduction in natural and traditional farming as reported by Bhosale, (2013) and Kanade and Bhosale (2013).

\section{References}

Bhosale R. S. (2013) Decline in Traditional Millet farming in Tribal Trace Areas of Mahabaleshwar Taluka a Hazard to Ecosystem, Int. Res. J. of Sci. \& Engg,1 (2):69-70.

Jansen, P.C.M., (2004). Amaranthus viridisL. In: Grubben, G.J.H. \& Denton, O.A. (Editors). PROTA 2: Vegetables/Légumes. [CD-Rom]. PROTA, Wageningen, Netherlands.

Kanade, A. M. and Bhosale, R. S. (2013) Decline in Traditional Millet Farming in Tribal Trace Areas of Ambegaon Taluka.Ad. Plant. Sci. 26(II): 211-212.

Mishra, S. B.,Verma, A., Mukerjee, A. andMadhavan, V. (2012)Amaranthus spinosus L. (Amaranthaceae) leaf extract attenuatesstreptozotocin-nicotinamide induced diabetes and oxidative stress inalbino rats: A histopathological analysisAsian Pacific Journal of Tropical Biomedicine S1647-S1652

Paola Vanzani, Monica Rossetto, Veronica De Marco, Linda E. Sacchetti, Maurizio G. Paoletti, AdelioRigo(2011) Wild Mediterranean Plants as Traditional Food: A Valuable Source of Antioxidants Journal of Food Science 1750-3841.

Patil, M.V. and Patil, D.A. (2000) Some more Wild Edible Plants of Nasik District(Maharashtra) Ancient Science of Life Vol. No Xix (3\&4).

Rouhollah A., Faezeh M., Kazem G., Adel D Mohammadi-Nasab1and Parisa Z (2012) Allelopathic assessment of common amaranth by ECAM International Research Journal of Applied and Basic Sciences, Science Explorer Publications, Available online at www.irjabs.com Vol, 3 (11): 2268-2272.

Sasi R., Rajendran A and Maharajan M. (2011) Wild edible plant Diversity of Kotagiri Hills - a Part of Nilgiri Biosphere Reserve, Southern India. Journal of research in Biology 2: 80-87. 